\title{
Fibrinogen Level among Sudanese Patients with Chronic Myeloid Leukemia
}

\author{
Tagreed Saif Aldeen Mostafa ${ }^{1,2}$, Maye M. Merghani ${ }^{2}$, Nihad Elsadig Babiker ${ }^{1,3,4, *}$
}

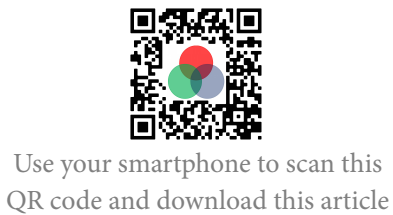

${ }^{1}$ Faculty of Medical Laboratory Sciences, National University, Sudan

${ }^{2}$ Nahda college, Sudan

${ }^{3}$ Darfur University College, Sudan

${ }^{4}$ National Center of Neurological Sciences, Sudan

Correspondence

Nihad Elsadig Babiker, Faculty of Medical Laboratory Sciences, National University, Sudan

Darfur University College, Sudan

National Center of Neurological Sciences, Sudan

Email: nihadelsadig@yahoo.com

History

- Received: Sep 02, 2021

- Accepted: Sep 29, 2021

- Published: Oct 04, 2021

DOI : 10.15419/ajhs.v7i2.493

\section{Check for updates}

Copyright

(- Biomedpress. This is an openaccess article distributed under the terms of the Creative Commons Attribution 4.0 International license.

\begin{abstract}
Background: Chronic myeloid leukemia $(\mathrm{CML})$ is a malignancy of white blood cells, distinguished by the Philadelphia chromosome's presence. The biological profile of sufferers with CML at diagnosis is nevertheless missing in Africa, especially in Sudan. Therefore, the study pursued to measure the fibrinogen level among Sudanese patients diagnosed with CML attending the Radiation and Isotopes Centre of Khartoum. Methods: This descriptive perspective and the analytical casecontrol study were performed at the Radiation and Isotopes Centre of Khartoum from August to September 2021. In this study, fifty patients with CML were utilized as a case, and 50 healthy people were used as a control group. The blood samples from groups were collected in sodium citrate anticoagulant containers. Fibrinogen levels in the blood were determined by the Clauss technique using a coagulometer device. Results: There was a significant increase in fibrinogen levels between case and control groups. Further, age, gender, family history, and presence of chronic disease were non-significantly variations in CML patients. Moreover, smoking was considered a risk factor in CML. Conclusions: Fibrinogen level was significantly elevated in CML patients; additionally, there were significant differences associated with smoking, and there were non-significant differences related to age, gender, family history, presence of chronic disorder, and treatment.

Key words: Chronic Myeloid Leukemia, Coagulometer, Fibrinogen, Neoplasia
\end{abstract}

\section{INTRODUCTION}

Chronic myeloid leukemia (CML) is a malignancy of white blood cells; it is a sort of leukemia described by the expansion and out-of-control growth of predominantly myeloid cells within the bone marrow and the gathering of those cells in the blood ${ }^{1}$. CML was the fundamental malignancy related to clear genetic abnormality, which occurs in chromosomal translocation identified as the Philadelphia chromosome. In this movement, fragments of two chromosomes $\left(9^{\text {th }}\right.$ and $22^{\text {nd }}$ ) transfer locations, a piece of the BCR smash point cluster region from chromosome 22 is fused with the ABL gene on chromosome 9 this uncommon "fusion" gene ${ }^{2}$.

Fibrinogen is a solvent protein inside the plasma; this is broken down to fibrin through the enzyme thrombin to form clots. The reference range for the extraordinary fibrinogen tests is as follows: fibrinogen antigen 149 - $353 \mathrm{mg} / \mathrm{dL}$, fibrinogen $150-400 \mathrm{mg} / \mathrm{dL}$, fibrinogen antigen/functional ratio: $0.59-1.23$. Regular fibrinogen activity results normally reflect regular blood clotting potential ${ }^{3}$.

Fibrinogen is an acute-phase reactant, implying that raised fibrinogen levels can be apparent in subsequent situations: infection, tissue damage/trauma, most cancers, acute coronary syndrome, strokes, and inflammatory conditions ${ }^{3,4}$.

CML is recognized by a derangement of various parts of the hemostatic system that appear to have thrombo-hemorrhagic complications. Regardless of unusual than different myeloproliferative neoplasms, derangement of different additives of the hemostatic system is seen in CML. Hemostatic abnormalities were described in relation to hyperleucostasis and drugs utilized to treat CML. But, the literature revealed the fibrinogen level is raised in $\mathrm{CML}^{5}$. Therefore, CML patients suffer from many abnormalities that could affect their hemostatic status and might result in bleeding and thrombosis, affecting their survival. So the patients need to frequently check-up for their hemostatic reputation. This study was performed to measure fibrinogen levels in leukemic patients to assist in early detection of any risk that may result in more significant complications, leading to loss of life.

\section{METHODS}

This is a descriptive prospective, and analytical casecontrol study carried out at the Radiation and Isotopes center of Khartoum (RICK) from August to September 2021. 


\section{Inclusion criteria}

Sudanese patients diagnosed with chronic leukemia who attended the Radiation and Isotopes center of Khartoum during the study and accepted to participate in this study were included as a case group and healthful individuals as control with matched age.

\section{Exclusion criteria}

Patients with any recently identified hemostatic disease, any family history of bleeding disease, ingesting drugs recognized to affect the hemostatic system, any liver disease, renal disorder, any systemic infection probably to affect hemostasis, pregnant patients, and patients not inclined to present their consent were excluded from the study.

$1.8 \mathrm{ml}$ of blood was collected from every member (case \& control) in a trisodium citrate container and then obtained the plasma for fibrinogen level determination.

The fibrinogen concentration was measured using a semi-automated coagulometer after dilution of plasma using buffer (thrombin buffer). The coagulometer clot has an optical measurement, which detects a sudden variation in optical density when the clot is formed. A sudden change of optical density activates the chronometer and stirring system. This permits the initiation of time measurement when the sample is added to the reagents and stops measurement time when the clot is formed. The continuous mixing ideally guarantees homogenization, making the measurement possible of low fibrinogen concentration by grouping the fibrinogen filaments in the center of the optical pass. In addition, the system has programmable security time during which variation in optical density, when the reagent and plasma are still in homogenization phase, cannot activate the detection cell.

In this study individually designed questionnaire was used for data collection; SPSS 13.0 statistical program (SPSS Inc., USA) was utilized for statistical analysis (frequency, independent T-test, Anova). The ethical approval to carry out the study was taken from the National University committee, and all information, specimens, and results obtained from patients were considered high-security data.

\section{RESULTS}

\section{The epidemiological study}

In the current study, $50 \mathrm{CML}$ patients have been incorporated. Among those, 52\% had been males, while
$48 \%$ were females. Furthermore, 50 healthful individuals were selected as the control group; $52 \%$ were adult males, while $48 \%$ had been female (Table 1) (Figure 1). Maximum influenced age group in the patients between 30 - 50 years followed via more than 50 years which constituted $48 \%$ and $28 \%$, respectively (Table 2) (Figure 1).

\section{The hematological study}

When compared the fibrinogen level between cases and control group there was significant differences with $(\mathrm{P}=0.000)$ (Table 4$)$. Also in the case group there was significant differences between the smoking and fibrinogen level $(P=0.049)$, non-significant differences between age $(\mathrm{p}=0.318,0.214,0.777$ respectively) (Table 5), gender ( $\mathrm{p}=0.734)$, family history ( $\mathrm{p}$ $=0.951), \mathrm{DM}(\mathrm{P}=0.952)$ hypertension $(\mathrm{p}=0.577)$, autoimmune $(\mathrm{p}=0.175)$, treatment $(\mathrm{p}=0.373)$ and fibrinogen level (Table 6).

\section{DISCUSSION}

This study was carried out at the Radiation and Isotopes center of Khartoum (RICK) from August to September 2021 to measure fibrinogen levels in CML patients. The collected data were analyzed using the statistical package of the social science (SPSS) program. There was new vision revealed using this study showed that the male: female ratio was 1.1: 1 . This finding supports AnKur et al. study, which found out that in CML, males are influenced more frequently than females (ratio of $1.3-2.2$ to 1 ) because women have protection because of increased expression of tumor suppressor genes ${ }^{6,7}$.

This study indicated that the most affected age group was 30 - 50 years, that's constant with the different study which mentioned the prevalence of CML will increase with age ${ }^{8}$.

When compared the fibrinogen level among cases and controls groups, there was a highly significant rise in the fibrinogen level of cases. This result is consistent with Evica et al., which determined that fibrinogen levels are increased in $36.27 \%$ of the CML patients ${ }^{9}$. Abegunde et al. also inferred that increased fibrinogen levels are a risk factor for thrombosis in these patients ${ }^{10}$. This hyperfibrinogenemia may be explained because the growth of tumor cells impacts homeostasis by activating the coagulation cascade, which promotes thrombin formation ${ }^{11}$. Moreover, tumors cells typically secret chemokines, cytokines, and prostaglandins that enhance the recruitment of inflammatory cells resulting in an increase of fibrinogen level as an acute-phase protein ${ }^{12}$. 
Table 1: Distribution of gender in the study group

\begin{tabular}{lccc}
\hline Study group & Gender & Frequency & Percentage \\
\hline Case & Male & 24 & 48.0 \\
& Female & 26 & 52.0 \\
& Total & 50 & 100.0 \\
Control & Male & 24 & 48.0 \\
& Female & 26 & 52.0 \\
& Total & 50 & 100.0 \\
\hline
\end{tabular}
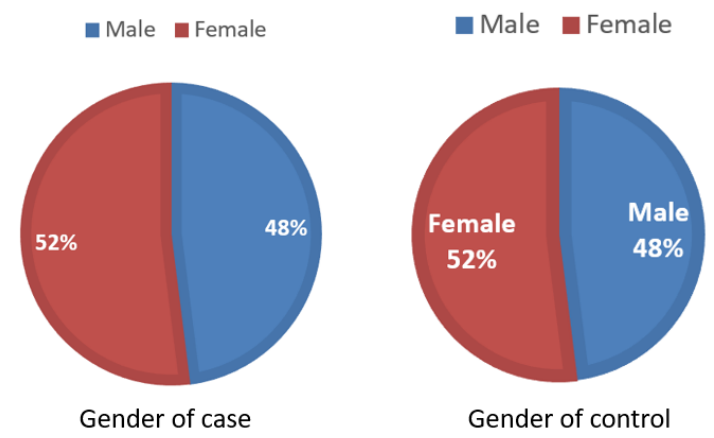

— 30 years $\quad 30-50$ years $\square>50$ years

Figure 1: Distribution of gender in case and control groups, and the age in the case group.

Table 2: Age groups of affected patients

\begin{tabular}{ccc}
\hline Age & Frequency & Percentage \\
\hline$<30$ years & 13 & 26.0 \\
30 - 50 years & 23 & 46.0 \\
$>50$ years & 14 & 28.0 \\
Total & 50 & 100.0 \\
\hline
\end{tabular}

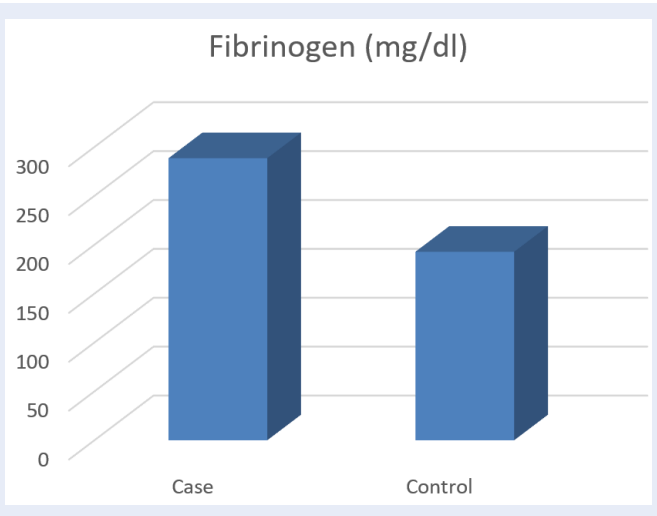

Figure 2: Mean of fibrinogen among the study group. 
Table 3: Distribution of other studied variables in the case group

\begin{tabular}{|c|c|c|c|}
\hline Variables & & Frequency & Percentage \\
\hline \multirow[t]{3}{*}{ Family history } & Yes & 15 & 30.0 \\
\hline & No & 35 & 70.0 \\
\hline & Total & 50 & 100.0 \\
\hline \multirow[t]{3}{*}{ Smoking } & Yes & 18 & 36.0 \\
\hline & No & 32 & 64.0 \\
\hline & Total & 50 & 100.0 \\
\hline Alcohol & No & 50 & 100.0 \\
\hline \multirow[t]{3}{*}{$\mathrm{DM}$} & Yes & 25 & 50.0 \\
\hline & No & 25 & 50.0 \\
\hline & Total & 50 & 100.0 \\
\hline \multirow[t]{3}{*}{ Hypertension } & Yes & 17 & 34.0 \\
\hline & No & 33 & 66.0 \\
\hline & Total & 50 & 100.0 \\
\hline \multirow[t]{3}{*}{ Autoimmune } & Yes & 7 & 14.0 \\
\hline & No & 43 & 86.0 \\
\hline & Total & 50 & 100.0 \\
\hline \multirow[t]{3}{*}{ Treatment } & Chemotherapy & 31 & 62.0 \\
\hline & Radiotherapy & 19 & 38.0 \\
\hline & Total & 50 & 100.0 \\
\hline
\end{tabular}

Table 4: Comparison of fibrinogen level among the study group

\begin{tabular}{|c|c|c|c|c|c|c|}
\hline Variables & & Minimum & Maximum & Mean & $\begin{array}{c}\text { Std. } \\
\text { Deviation }\end{array}$ & P-value \\
\hline \multicolumn{7}{|l|}{ Case } \\
\hline $\begin{array}{l}\text { Fibrinogen } \\
(\mathrm{mg} / \mathrm{dl})\end{array}$ & 50 & 204 & 402 & 288.5 & 44.2 & \\
\hline \multicolumn{7}{|l|}{ Control } \\
\hline $\begin{array}{l}\text { Fibrinogen } \\
(\mathrm{mg} / \mathrm{dl})\end{array}$ & 50 & 163 & 227 & 192.8 & 19.9 & \\
\hline & & & & & & $0.000^{*}$ \\
\hline
\end{tabular}

In the current study, there was a non-significant difference in fibrinogen level in age (years) (p-value $\geq$ 0.05 ), gender ( $p$-value $\geq 0.734$ ), and family history ( $p$ value $=0.951$ ) of CML patients. On the other hand, there was a significant difference in fibrinogen level in smoker CML patients ( $\mathrm{p}$-value $=0.049$ ). Many research emphasized that smoking is the most vital and most common risk issue in youth patients ${ }^{13}$.

Similarly, there was a non-significant difference in fibrinogen level when compared among the patients with different chronic diseases such as DM ( $\mathrm{p}$-value $=0.952)$, HT (p-value $=0.577)$, and autoimmune disease ( $p$-value $=0.178)$ which result agreed with study showed that diabetes and HTN isn't any independent predictor of hyper-fibrinogenemia ${ }^{14}$.

Finally, there was no significant difference in fibrinogen level when compared between the patients treated by chemotherapy and patients treated by radiotherapy ( $p$-value $=0.373)$. This finding agreed with the previous study that revealed that blood fibrinogen con- 
Table 5: Comparison of fibrinogen level among other studied variables in the case group

\begin{tabular}{|c|c|c|c|}
\hline Variables & & Fibrinogen (mg/dl) & P-value \\
\hline \multirow[t]{2}{*}{ Gender } & Male $(\mathrm{n}=24)$ & $286.4 \pm 46.4$ & \multirow[t]{2}{*}{0.734} \\
\hline & Female $(n=26)$ & $290.5 \pm 42.9$ & \\
\hline \multirow[t]{2}{*}{ Family history } & Yes $(n=15)$ & $289.1 \pm 50.7$ & 0.951 \\
\hline & No $(n=35)$ & $288.3 \pm 41.9$ & \multirow{3}{*}{$0.049^{*}$} \\
\hline \multirow[t]{2}{*}{ Smoking } & Yes $(n=18)$ & $272.2 \pm 39.2$ & \\
\hline & No $(\mathrm{n}=32)$ & $297.8 \pm 44.8$ & \\
\hline $\mathrm{DM}$ & Yes $(n=25)$ & $288.9 \pm 37.6$ & 0.952 \\
\hline \multirow{3}{*}{ Hypertension } & No $(n=25)$ & $288.2 \pm 50.8$ & \multirow{3}{*}{0.577} \\
\hline & Yes $(n=17)$ & $293.5 \pm 32.8$ & \\
\hline & No $(n=33)$ & $286.0 \pm 49.4$ & \\
\hline Autoimmune & Yes $(n=7)$ & $309.6 \pm 36.5$ & 0.178 \\
\hline \multirow{3}{*}{ Treatment } & No $(n=43)$ & $285.1 \pm 44.8$ & \multirow{3}{*}{0.373} \\
\hline & Chemotherapy $(\mathrm{n}=31)$ & $284.1 \pm 46.2$ & \\
\hline & Radiotherapy $(\mathrm{n}=19)$ & $295.7 \pm 41.1$ & \\
\hline
\end{tabular}

Table 6: Comparison of fibrinogen level among other studied variables in the case group

\begin{tabular}{|c|c|c|c|}
\hline Variables & & Fibrinogen (mg/dl) & P-value \\
\hline \multirow[t]{2}{*}{ Gender } & Male $(\mathrm{n}=24)$ & $286.4 \pm 46.4$ & 0.734 \\
\hline & Female $(n=26)$ & $290.5 \pm 42.9$ & \\
\hline \multirow[t]{2}{*}{ Family history } & Yes $(\mathrm{n}=15)$ & $289.1 \pm 50.7$ & 0.951 \\
\hline & No $(\mathrm{n}=35)$ & $288.3 \pm 41.9$ & \\
\hline \multirow[t]{2}{*}{ Smoking } & Yes $(\mathrm{n}=18)$ & $272.2 \pm 39.2$ & $0.049^{*}$ \\
\hline & No $(\mathrm{n}=32)$ & $297.8 \pm 44.8$ & \\
\hline \multirow[t]{2}{*}{$\mathrm{DM}$} & Yes $(n=25)$ & $288.9 \pm 37.6$ & 0.952 \\
\hline & No $(n=25)$ & $288.2 \pm 50.8$ & \\
\hline \multirow[t]{2}{*}{ Hypertension } & Yes $(n=17)$ & $293.5 \pm 32.8$ & 0.577 \\
\hline & No $(\mathrm{n}=33)$ & $286.0 \pm 49.4$ & \\
\hline \multirow[t]{2}{*}{ Autoimmune } & Yes $(n=7)$ & $309.6 \pm 36.5$ & 0.178 \\
\hline & No $(\mathrm{n}=43)$ & $285.1 \pm 44.8$ & \\
\hline \multirow[t]{2}{*}{ Treatment } & Chemotherapy $(\mathrm{n}=31)$ & $284.1 \pm 46.2$ & 0.373 \\
\hline & Radiotherapy $(\mathrm{n}=19)$ & $295.7 \pm 41.1$ & \\
\hline
\end{tabular}


centration decreases in patients with primary tumors after chemotherapy ${ }^{15}$.

\section{CONCLUSIONS}

This study showed that the fibrinogen levels in blood were significantly raised in the CML patients. In addition, there were significant differences associated with smoking. On the other hand, there were nonsignificant differences in age, gender, family history, presence of chronic disorder, and treatment. To adopt this result study with larger samples and a more extended period should be conducted to evaluate coagulation and fibrinolysis parameters which might have varying results than the present study results.

\section{ABBREVIATIONS \\ CML: Chronic myeloid leukemia \\ DM: Diabetes Millets \\ HT: Hyper Tension \\ RICK: Radiation and Isotopes center of Khartoum \\ SPSS: Statistical Package Of Social Science}

\section{ACKNOWLEDGMENTS}

The authors acknowledge the personnel of the Radiation and Isotopes center of Khartoum, Sudan for their beneficial and support.

\section{AUTHOR'S CONTRIBUTIONS}

All composer similarly participated to this work , wrote, rectified and authorized this manuscript. All authors read and approved the final manuscript.

\section{FUNDING}

None.

\section{AVAILABILITY OF DATA AND MATERIALS}

Data and materials used and/or analyzed during the current study are available from the corresponding author on reasonable request.

\section{ETHICS APPROVAL AND CONSENT TO PARTICIPATE}

Not applicable.

\section{CONSENT FOR PUBLICATION}

Not applicable.

\section{COMPETING INTERESTS}

The authors declare that they have no competing interests.

\section{REFERENCES}

1. Mehta AB, Hoffbrand AV. Haematology at a Glance, the 2nd. Wiley-Blackwell, Oxford: P.P176-303; 2000.

2. Hehlamann R, Hochhaus A, Baccarani M. Chronic myeloid leukemia in the India.European LeukemiaNet. Lancet. 2007; *.*:342-5. Available from: 10.1016/S0140-6736(07) 61165-9.

3. Pagana KD, Pagana TJ. Blood Studies. Mosby's Manual of Diagnostic and Laboratory Tests. 4th ed. St. Louis: Mosby Elsevier Chap2; 2010.

4. Fischbach FT, Dunning MB. Overview of Chemistry Studies: Manual of Laboratory and Diagnostic Tests. 8th ed. Philadelphia: Lippincott Williams and Wilkins; chap. 6. Philadelphia: Lippincott Williams and Wilkins; 2009.

5. Jain A, Gupta N, Singh T, Agarwal S. A study of haemostatic parameters in patients of chronic myeloid leukaemia. Journal of clinical and diagnostic research: JCDR. 2016;10(7):OC19. Available from: 10.7860/JCDR/2016/19185.8135.

6. Jain A, Gupta N, Singh T, Agarwal S. A Study of Haemostatic Parameters in Patients of Chronic Myeloid Leukaemia. Journal of Clinical and Diagnostic Research : JCDR. 2016;10(7):19-23. PMID: 27630882. Available from: 10.7860/JCDR/2016/19185. 8135 .

7. Ning L, Hu C, Lu P, Que Y, Zhu X, Li D. Trends in disease burden of chronic myeloid leukemia at the global, regional, and national levels: a population-based epidemiologic study. Experimental Hematology \{\&amp;\}amp; Oncology. 2020;9(1):29. PMID: 33292593. Available from: 10.1186/s40164-020-00185$\mathrm{z}$.

8. Kantarjian HM, Giles FJ, O'Brien SM, Talpaz M. Clinical course and therapy of chronic myelogenous leukemia with interferon-alpha and chemotherapy. Hematology/Oncology Clinics of North America. 1998;12(1):31-80. PMID: 9523225. Available from: 10.1016/S0889-8588(05)70496-2.

9. Simonovic E, Macukanovic-Golubovic L, Milenovic M, Mladenovic M, Colic V. Basic biochemical parameters significant in diagnosis of myeloproliferative diseases. FactaUniversitatis, series. Medicine and Biology. 2007;14:82-7.

10. Abegunde SO, Famodu AA, Awodu OA, Ajayi IO, Ojeokun FA. Haemostatic and haemorrheological changes in African patients with chronic myeloid Leukaemia. Journal of Thrombosis and Haemostasis. 2009;7(suppl 2):PP-TH-501.

11. Wang X, Wang E, Kavanagh JJ, Freedman RS. Ovarian cancer, the coagulation pathway, and inflammation. Journal of Translational Medicine. 2005;3(1):25. PMID: 15969748. Available from: 10.1186/1479-5876-3-25.

12. Jaffe ES, Harris NL, Stein H. Pathology and Genetics of Tumours of Hematopoietic and Lymphoid Tissues, vol 3. IARC press, 2001. 2001;

13. Thomas AE, Green FR, Kelleher CH, Wilkes HC, Brennan PJ, Meade TW. Variation in the promoter region of the beta fibrinogen gene is associated with plasma fibrinogen levels in smokers and non-smokers. Thrombosis and Haemostasis. 1991;65(5):487-90. PMID: 1871708. Available from: 10.1055/ s-0038- 1648177.

14. Giovine GD, Verdoia M, Barbieri L, Schaffer A, Aimaretti G, Bellomo $G$, et al. Impact of diabetes on fibrinogen levels and its relationship with platelet reactivity and coronary artery disease: A single-centre study. Diabetes Research and Clinical Practice. 2015;109(3):541-50. PMID: 26163440. Available from: 10.1016/j.diabres.2015.05.038.

15. Lu DY, Chen XL, Cao JY, Li Z, Xue HW, Luo LJ. Effects of cancer chemotherapy on the blood fibrinogen concentrations of cancer patients. The Journal of International Medical Research. 2000;28(6):313-7. PMID: 11191725. Available from: $10.1177 / 147323000002800608$. 
Ready to submit your manuscript? Choose Biomedpress and benefit from:

- Fast, convenient online submission

- Through peer-review by experienced researchers

- Rapid publication on acceptance

- Free of charge (without publication fees)

Learn more http://www.biomedpress.org/journals/

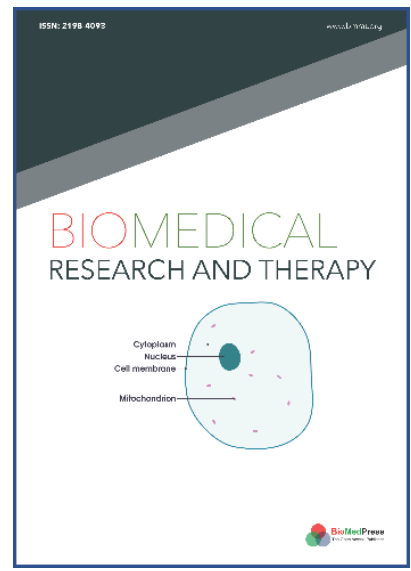

\title{
Biomedical Research and Therapy
}

Indexed: Web of Science (ESCl), Embase, Google Scholar

Journal Citation Indicator (2020): 0.16

Acceptance Rate (2020): 54.32\%

Article Publishing Charge: Free

Submission to first editorial decision: 27 days

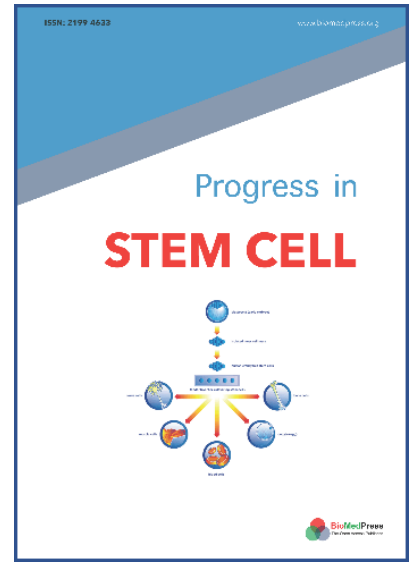

\section{Progress in Stem Cell}

Indexed: Embase, Google Scholar

Acceptance Rate (2020): 78.19\%

Article Publishing Charge: Free

Submission to first editorial decision: 19 days

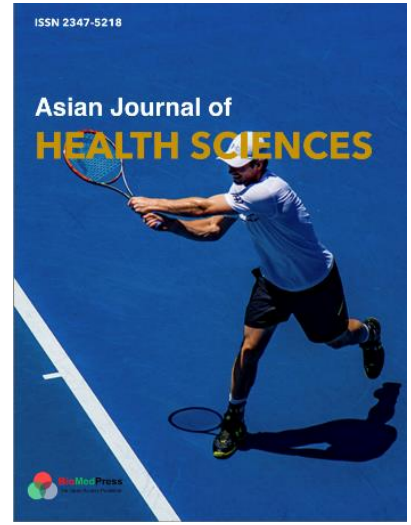

\author{
Asian Journal of Health Sciences \\ Indexed: Google Scholar \\ Acceptance Rate (2020): 72.89\% \\ Article Publishing Charge: Free \\ Submission to first editorial decision: 16.5 days
}

